\title{
USING SONG TO IMPROVE VOCABULARY MASTERY FOR ELEMENTARY SCHOOL
}

\author{
Amelia Ramadini $^{1}$, Author-name Siti Halimah ${ }^{2}$ \\ ${ }^{1}$ IKIP Siliwangi \\ ${ }^{2}$ IKIP Siliwangi \\ ${ }^{1}$ ramadiniamelia@gmail.com, ${ }^{2}$ sitihalimahsyadiah@gmail.com
}

\begin{abstract}
The purpose of this reseach is to know how the use song to improve the students' vocabulary mastery in learning English for elementary school students. The population of this research is SD Lebak Gede it consist thirty student. To analyzed the data the research using SPSS versi 17.0. The test of normality is feris step to know the data is normality distributed. Kolmogorov-smirnov test was used in this research, it can be seen the significant of Kolmogorov-smirnov from pretest was 0.36 and posttest was 0.30 is higher than 0.50 . It means that the data is normality distributed. The t-observed of pretest is 21.921 and t-observed of posttest was 56.550. The degree of freedom (df) 29 is 1.691 . It means that tobserved of this research is higher than the t-table. The significance (2-tailed) of the data was 0.000 is lower than 0.05. It menas that the data of pretest and posttest is significant. Minimum score pretest was 30 and the maximum score pretest was 80 , and the minimum score of posttest was 70 and maximum of posttest was 100. The mean of pretest score 54.60 and the mean of posttest was 81.07 . The standard deviation of pretest was 13.642 and standar deviation of posttest was 7.852 . It means, the data was improvement. Found that teaching vocabulary mastery using song for elementary school is effective.
\end{abstract}

Keywords: Teaching, Vocabulary, Song

\section{INTRODUCTION}

Language is the most important element to communication in all aspects of life, and English is an important language because it is used as an International language. Vocabulary is one of the important component to be taught to students. (Susanti \& Wijaya, 2013) argue that the success learning a foreign language is assumed in the term of the ability to communicate by using English. Therefore students should be able to have enough vocabulary. Vocabulary is increasingly as a critical component to language learning.

Teaching is activity to improve students' achievement. The purpose of the teaching is getting students understand what the material being taught. Not only get understand, as well as getting memorizing which is material had been taught. Teaching vocabulary for young learner be a challenge. Because it is easy for young learners to memorize and easy to forget what they have learn. Some technique can used to motivate students in particular young learners to learn the

vocabulary. The technique should be interesting and get attention from students. Such as vocabulary games, pictures, song, video or other media that can motivated students to enjoy learn English and have a long term memory what have been learned. (Muflihah, 2016) argue that language teacher should provide extensive knowledge on teaching and learning vocabulary. This deals with how to manage an interesting classroom activity so that the learners achieve a great success in their vocabulary learning.

Based on those reasons, it is believed that songs as one of the fun way of teaching to students in particular young learners to improve vocabulary mastery. The aimed of this research is to know the effectiveness of using song in improving vocabulary mastery for elementary school. 


\section{Definition of vocabulary}

According to (Fran Lehr, M. A., Jean Osborn, 2004) vocabulary is knowledge of words and word meaning. Meanwhile, according to Hatch and Brown (1995) vocabulary is a list of set of words for a particular language or a list or set of words that individual speakers of language might use (Rahmawati, 2014).There are two kinds of vocabulary, there are function word and content words. Function words are used chiefly to express grammatical function, while content words are used to express part of speech and consist a noun, verbs, adjective and adverbs to make the largest part of vocabulary (Susanti \& Wijaya, 2013). From the definition above, vocabulary is the basic in learning foreign language, and for improve other language skills such as listening, speaking, reading, moreover writing will be difficult to be learned without knowing a lot of vocabulary, and used for communicate with each other.

\section{Definition of song}

According to Oxford Advanced Learners' Dictionary (2000) cited in (Avina, 2016), song is define as a pattern of sounds made by musical instrument with word that you can sing and intended to give pleasure people listening to it.

\section{Definition of young learners}

Piaget in (Pinter, 2006) claimed that teaching young learners can mean working with very different age groups with different interest and needs, as follow: 1. Sensori-motor stage (from 0 to 2 years of age) interact with the environment by manipulating object around him, 2. Preoperational stage (from 2 to 7 years of age) the child thinking is largely reliant on perception but he or she gradually become more and more capable of logical thinking, 3. Concrete operational stage (from 7 to 11 years of age) children thinking beings to resemble 'logical' adult-like thinking , 4. Formal operational stage (from 11 onwards) children are able to think beyond the immediate context in more abstract terms.

\section{Teaching vocabulary using song}

(Suri, 2012) argue that teaching vocabulary is a process or a unit of ways to make students learn or acquire vocabulary that is presented by the teacher. Song have been part of human experience. By using song, teaching learning process can be fun. According Nambiar (1980:80) cited in (Suri, 2012), "song introduce an atmosphere of fun, and informality in the classroom that is a far more conductive environment for language learning than a strictly regimented atmosphere. When the atmosphere the class is fresh, it wills a guarantee that the students feel fresh in learning vocabulary"

Using song to improve English vocabulary provides many benefits. Using song is effective tool to motivated students to learning new vocabulary. According (Fadli. M, 2008) There are several benefit of using songs in the classroom are song can be used to, the first is to present a topic, a language point, lexis, etc. The second is to practice a language point, lexis, etc. The third is to focus on common learner errors in a more direct way. The fourth is to encourage extensive and intensive listening. The fifth is to stimulate discussion on attitude and feeling. The sixth is to encourage creativity and use of imagination. The seventh is to provide a relaxed classroom atmosphere. The last is to bring variety and fun learning.

According to Lynch (2008) cited in (Fadli. M, 2008) criteria of choosing song are three point. The first is use song that are popular with the students whenever possible. Unfortunately, students frequently select songs for classroom use which are objectionable in some way making 
the song unusable. The second is songs must have clear and understandable lyrics. Nothing is worse than a song almost nobody can understand. If you have trouble understanding the lyric by listening, then another song need to be selected. The last is songs should have an appropriate theme. There's enough bad news, negativity and violence in the world already. Songs with any type of negative theme should be avoided. There are plenty of positive, upbeat, even humorous songs available. From the criteria above, songs should be chosenthough the level of difficulty, song should be clear lyric and easy to understand,should be known whether the students going like the song or not and it's better to choose a song that is popular but doesn't contain negative elements.

\section{METHOD}

In this research, the writer chose pre-experimental method with one group pretest-posttest design. In experimental method are one group, one case shot study design and one group pretest-posttest. Meanwhile, the one group pretest, posttest design involves, three steps: The first step is the administration of pretest measuring the dependent variable.The second step is the application of the experimental treatment (independent variable) to the subject and the final step is the administration of posttest measuring the dependent variable again. (Kaswan \& Dasep, 2013). The population of this research is SDN Lebak Gede fourth grade, it consist thirty students.

\section{RESULTS AND DISCUSSION}

\section{Results}

This part display the analysis the data have been collected by pretest and posttest.

Table 1. The Result of pretest and posttest

\begin{tabular}{lll}
\hline Name of students & Pretest & \multicolumn{2}{c}{ Posttest } \\
\hline Student 1 & 70 & 100 \\
\hline student 2 & 43 & 80 \\
\hline Student 3 & 40 & 76 \\
\hline Student 4 & 60 & 86 \\
\hline Student 5 & 70 & 73 \\
\hline Student 6 & 50 & 86 \\
\hline Student 7 & 47 & 76 \\
\hline Student 8 & 43 & 73 \\
\hline Student 9 & 43 & 86 \\
\hline Student 10 & 60 & 76 \\
\hline Student 11 & 50 & 73 \\
\hline Student 12 & 70 & 86 \\
\hline Student 13 & 50 & 73 \\
\hline Student 14 & 30 & 86 \\
\hline Student 15 & 50 & 80 \\
\hline Student 16 & 40 & 73 \\
\hline Student 17 & 80 & 86 \\
\hline Student 18 & 43 & 93 \\
\hline
\end{tabular}




\begin{tabular}{lll}
\hline Student 19 & 70 & 80 \\
\hline Student 20 & 80 & 80 \\
\hline Student 21 & 70 & 93 \\
\hline Student 22 & 60 & 73 \\
\hline Student 23 & 50 & 70 \\
\hline Student 24 & 30 & 86 \\
\hline Student 25 & 50 & 86 \\
\hline Student 26 & 70 & 80 \\
\hline Student 27 & 43 & 70 \\
\hline Student 28 & 63 & 73 \\
\hline Student 29 & 60 & 93 \\
\hline Student 30 & 53 & 86 \\
\hline
\end{tabular}

In this research, the writer using SPSS versi 17.0 to analyzed the data on the table below:

Table 2. Tests of Normality

\begin{tabular}{lccccccr}
\hline & \multicolumn{3}{c}{ Kolmogorov-Smirnov $^{\mathrm{a}}$} & \multicolumn{3}{c}{ Shapiro-Wilk } \\
\hline & Statistic & $\mathrm{df}$ & & Sig. & Statistic & Df & \multicolumn{2}{c}{ Sig. } \\
\hline Pretest & .165 & 30 & .036 & .947 & 30 & .139 \\
Posttest & .168 & 30 & .030 & .917 & 30 & .023 \\
\hline
\end{tabular}

a. Lilliefors Significance Correction

From the result above, the test of normality is feris step to know the data is normality distributed. Kolmogorov-smirnov test was used in this research. Based on the table 2, it can be seen the significant of Kolmogorov-smirnov from pretest was 0.36 and posttest was 0.30 is higher than 0.50 . it means that the data is normality distributed.

Table 3. One-Sample Statistics

\begin{tabular}{|c|c|c|c|c|}
\hline & $\mathrm{N}$ & Mean & Std. Deviation & Std. Error Mean \\
\hline pretest & 30 & 54.60 & 13.642 & 2.491 \\
\hline posttest & 30 & 81.07 & 7.852 & 1.434 \\
\hline
\end{tabular}

Table 4. One-Sample Test

Test Value $=0$

$95 \%$ Confidence Interval of the Difference

\begin{tabular}{llllll}
\hline$T$ & df & Sig. (2-tailed) & Mean Difference & Lower & Upper \\
\hline
\end{tabular}




\begin{tabular}{lllllll}
\hline Pretest & 21.921 & 29 & .000 & 54.600 & 49.51 & 59.69 \\
Posttest & 56.550 & 29 & .000 & 81.067 & 78.13 & 84.00 \\
\hline
\end{tabular}

From the table 4, it can be seen that the t-observed of pretest is 21.921 and t-observed of posttest was 56.550. The degree of freedom (df) 29 is 1.691. it means that t-observed of this research of this research is higher than the t-table. The significance (2-tailed) of the data was 0.000 is lower than 0.05 . it menas that the data of pretest and posttest is significant.

Table 5. Descriptive Statistics

\begin{tabular}{lrrrrrrr}
\hline & $N$ & Minimum & Maximum & \multicolumn{2}{c}{ Mean } & \multicolumn{2}{c}{ Std. Deviation } \\
\hline & Statistic & \multicolumn{1}{c}{ Statistic } & Statistic & Statistic & Std. Error & \multicolumn{1}{c}{ Statistic } \\
\hline Pretest & 30 & 30 & 80 & 54.60 & 2.491 & 13.642 \\
Posttest & 30 & 70 & 100 & 81.07 & 1.434 & 7.852 \\
Valid N (listwise) & 30 & & & & & \\
\hline
\end{tabular}

Based on the table 5 describe of minimum score pretest was 30 and the maximum score pretest was 80 , and the minimum score of posttest was 70 and maximum of posttest was 100 . The mean of pretest score 54.60 and the mean of posttest was 81.07. the standard deviation of pretest was 13.642 and standar deviation of posttest was 7.852. It menas, the data was improvement.

\section{Discussion}

The discusion of this research is, using song to improve vocabulary mistery for elementary school. the finding this research is minimum score pretest was 30 and the maximum score pretest was 80, and the minimum score of posttest was 70 and maximum of posttest was 100 . The mean of pretest score 54.60 and the mean of posttest was 81.07. the standard deviation of pretest was 13.642 and standar deviation of posttest was 7.852. the test of normality is first step to know the data is normality distributed. Kolmogorov-smirnov test was used in this research. Based on the table 1, it can be seen the significant of Kolmogorov-smirnov from pretest was 0.36 and posttest was 0.30 is higher than 0.50 . it means that the data is normality distributed. the t-observed of pretest is 21.921 and t-observed of posttest was 56.550. The degree of freedom (df) 29 is 1.691. it means that t-observed of this research of this research is higher than the ttable. The significance (2-tailed) of the data was 0.000 is lower than 0.05 . it menas that the data of pretest and posttest is significant. It means, the implemation of using song to improve vocabulary mastery is effective for elementary school.

\section{CONCLUSION}

This research conducted this research by using pre-experiemntal design one group pretest posttest. The population of this research is SDN Lebak Gede fourth grade, it consist thirty students. Based on the data it found that the implemation of using song to improve vocabulary mastery is effective for elementary school.

\section{ACKNOWLEDGMENTS}

Alhamdulillahirabbilalamin. Praise to Allah SWT. Lord of the world who has given the writer his blessing and strength to finish this research paper. Peace and salutation are always for 
Rasulullah SAW. During completing the research, the writer obtained many help, suggestion and motivation from many people. For that reason, the writer would like to honorable advisor, Cynantia Rahmijati.M.M.Pd which during the writer completing the research.

\section{REFERENCES}

Avina, N. (2016). Teaching Listening Using Song to Improve Vocabulary. Skripsi, English Education Program Language and Arts Department (STKIP) Siliwangi Bandung.

Fadli. M. (2008). Improving Students' Listening Skills by Using Songs (An Action Research at the Second Year Students of MA Pancasila Bengkulu 2008. Journal of Education.

Fran Lehr, M. A., Jean Osborn, D. E. H. H. (2004). A focus on vocabulary. United Stated: Pasific Resources for Education and Learning. United Stated: Pasific Resourcher for Education and Learning.

Kaswan, \& Dasep, S. (2013). Research in English language. Retrieved from STKIP Siliwangi Muflihah, T. (2016). Using Song to Improve Students' Vocabulary Mastery. Journal of Education.

Pinter, A. (2006). Teaching Young Language Learners. Oxford Unioversity Press.

Rahmawati, I. (2014). The Use of Pictures in Teaching Vocabulary for Children.

Suri, . E. M. (2012). Improving Students' Vocabulary Mastery by Using Songs at The Grade Sixth of State Elementary School of 45 BungoPasang Padang. Journal of Education. Journal of Education.

Susanti, E., \& Wijaya, B. (2013). Improving students' vocabulary by using song and game., 2 (4). Retrieved from http://portalgaruda.ilkom.unsri.ac.id. 